\title{
Global hydrogen reservoirs in basement and basins
}

\author{
John Parnell ${ }^{1 *}$ and Nigel Blamey ${ }^{1,2}$
}

\begin{abstract}
Background: Hydrogen is known to occur in the groundwaters of some ancient cratons. Where associated gases have been dated, their age extends up to a billion years, and the hydrogen is assumed also to be very old. These observations are interpreted to represent the radiolysis of water and hydration reactions and migration of hydrogen into fracture systems. A hitherto untested implication is that the overwhelming bulk of the ancient low-permeability basement, which is not adjacent to cross-cutting fractures, constitutes a reservoir for hydrogen.

Results: New data obtained from cold crushing to liberate volatiles from fluid inclusions confirm that granites and gneiss of Archean and Palaeoproterozoic (>1600 Ma) age typically contain an order of magnitude greater hydrogen in their entrained fluid than very young ( $<200 \mathrm{Ma}$ ) granites. Sedimentary rocks containing clasts of old basement also include a greater proportion of hydrogen than the young granites.

Conclusions: The data support the case for a global reservoir of hydrogen in both the ancient basement and in the extensive derived sediments. These reservoirs are susceptible to the release of hydrogen through a variety of mechanisms, including deformation, attrition to reduce grain size and diagenetic alteration, thereby contributing to the hydrogen required by chemolithoautotrophs in the deep biosphere.
\end{abstract}

Keywords: Hydrogen, Granites, Fluid inclusions, Deep biosphere

\section{Background}

Measurements of groundwaters in Precambrian cratons show that they consistently contain hydrogen (data reviewed in [1-3]). The hydrogen is attributed to the long-term radiolysis of water due to natural radioactivity [4] and hydration reactions, including serpentinization and oxidation of ferrous iron [2]. Evidence from noble gas composition shows that gases may have been trapped in the crust for up to a billion years [5-7], and although hydrogen is not dated directly, longevity is implied by the association with dated gases [5], and the genetic link between radiolysis and dated radiogenic helium.

The measurement of hydrogen has focussed on crystalline basement, rather than in sedimentary basins. Yet sedimentary basins are dominated by siliciclastic sediment, that sediment is dominated by the mineral quartz, and most quartz is derived from granites. More generally,

*Correspondence: J.Parnell@abdn.ac.uk

1 School of Geosciences, University of Aberdeen, Aberdeen AB24 3UE, UK Full list of author information is available at the end of the article siliciclastic sediment ultimately has a basement source, albeit recycled through phases of sedimentary deposition and erosion. An implication of the derivation from crystalline basement is that a signature of hydrogen in the basement could be conferred to the sediment. The ultimate provenance of sediment is evident from the dating of detrital zircon grains. Both modern sand, and sandstone in the geological record, contains a substantial proportion of grains derived from basement sources of early-mid Proterozoic age [8, 9]. This reflects an episode of anomalous crustal growth with globally extensive granite emplacement $[10,11]$. We therefore might expect the sediment to carry the heritage of the hydrogen-rich Precambrian basement. A significant proportion of the hydrogen generated by radiolysis in basement rocks, possibly two-thirds [2], is resident in fluid inclusions, and these inclusions survive in the derived sediment particles.

The composition of gases trapped in fluid inclusions can be measured using cold crushing into a mass spectrometer. This technique was developed for the 
investigation of ore deposits and geothermal systems, and has subsequently found application to diverse crystalline and sedimentary rocks [12-14]. We have used this approach to test:

1. If the hydrogen occurs widely in the entrapped fluid in old basement rocks, as implied by the gas released from Precambrian cratons.

2. If the importance of age can be demonstrated by comparison with data in young basement rocks.

3. If hydrogen also occurs in the derived sediment, as we predict here.

Most water in granitic basement is in post-magmatic secondary fluid inclusions, with only a comparatively minor component originating from the granite melt and forming glassy melt inclusions or rare primary aqueous fluid inclusions [15]. The secondary aqueous fluid inclusions in granites represent hydrothermal fluid from a range of origins, including fractionation of the original melt, convection systems driven by the hot magma, and later fluids focussed on the granite because it has become a structural/topographic high [16, 17]. The entrapped fluid in granitic basement is, therefore, a good record of its post-emplacement history.

\section{Methods}

We have tested the occurrence of hydrogen in Precambrian basement (Fig. 1) by measuring the composition of gases released by cold crushing of granitic/gneissose basement samples. We have also analysed a set of young granites, to test if age is a critical factor in gas composition. 25 samples older than $1600 \mathrm{Ma}$, and 17 samples younger than $200 \mathrm{Ma}$ were analysed (Fig. 2). Both old and young samples have a global distribution (Fig. 1). Where possible, the samples are granitoids. Some of the older samples are gneisses or conglomerates, which should have broadly comparable mineralogy and chemistry. Samples containing high concentrations of uranium were excluded, with the exception of the Moeda Formation conglomerate from Brazil. Further, we have analysed quartzose sediment derived from old and young basement, to test if gas signatures are preserved in clasts derived from erosion of basement. These analyses were restricted to unconsolidated sediment, to allow isolation of the individual clasts and avoid any contribution from mineral cements. A comparison was made using sediment derived from three Cenozoic and three Palaeoproterozoic granitic basement sources within a small area of crust in northwest Britain (Fig. 3). Quartz particles in sediment derived from Cenozoic granites in the

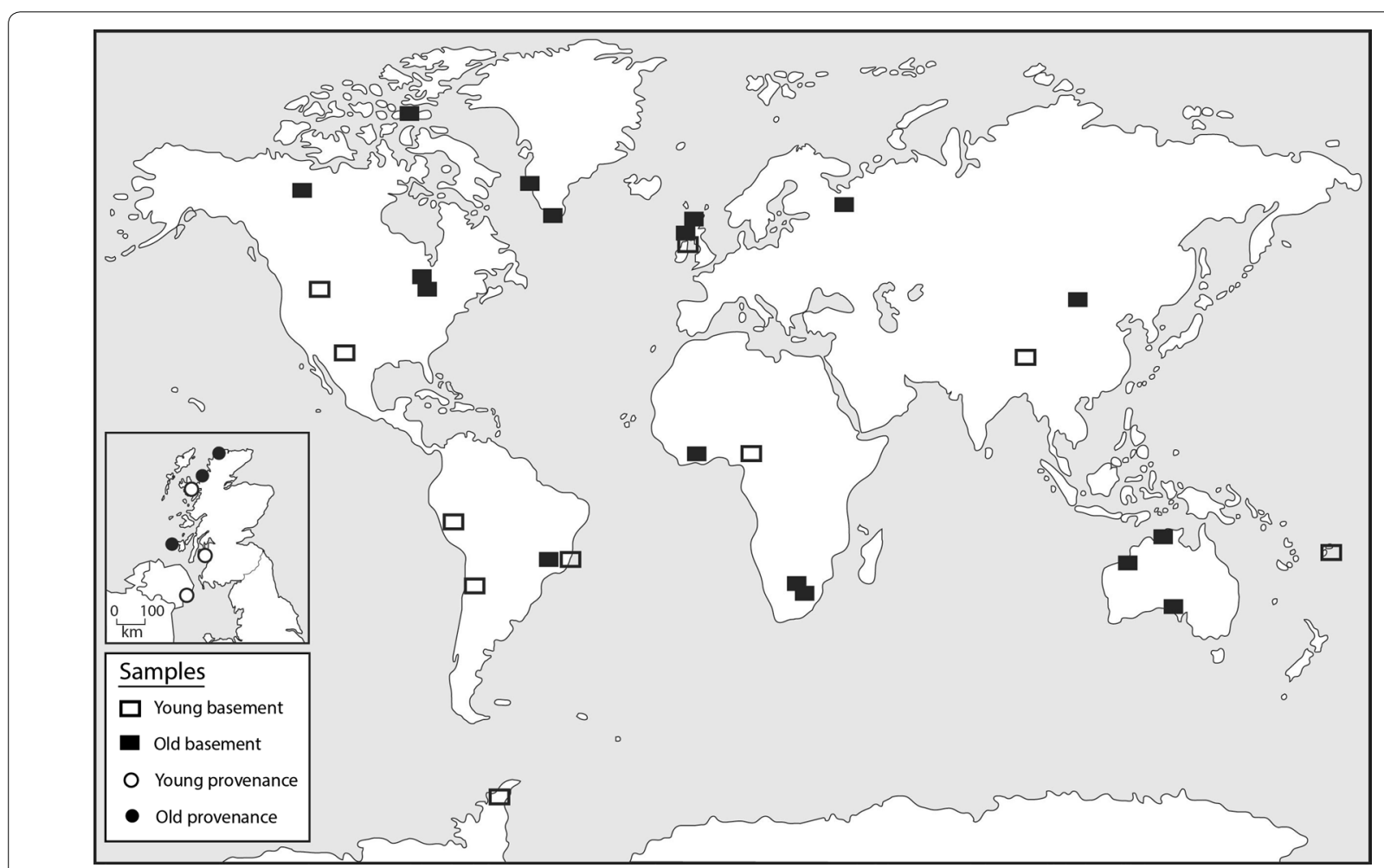

Fig. 1 Global map of young and old crystalline basement samples measured for hydrogen content. Inset shows map of sediment samples from Scotland and Ireland with provenance from young and old basement 


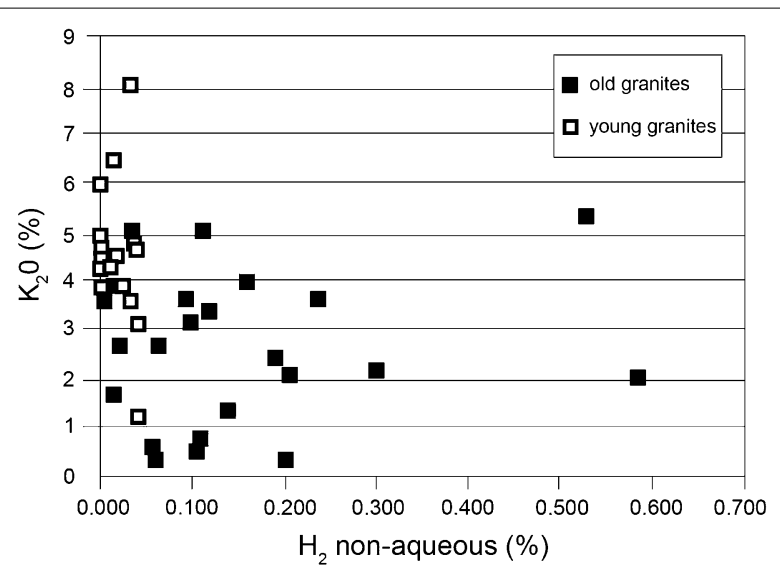

Fig. 2 Mean hydrogen contents (\% of non-aqueous gas) released by crushes of granitic and other basement rocks of Archean and Palaeoproterozoic age (>1.6 Ga) and young ( $<200 \mathrm{Ma}$ ) age, plotted against potassium content. (Data sources for ages and potassium contents in Table 1)

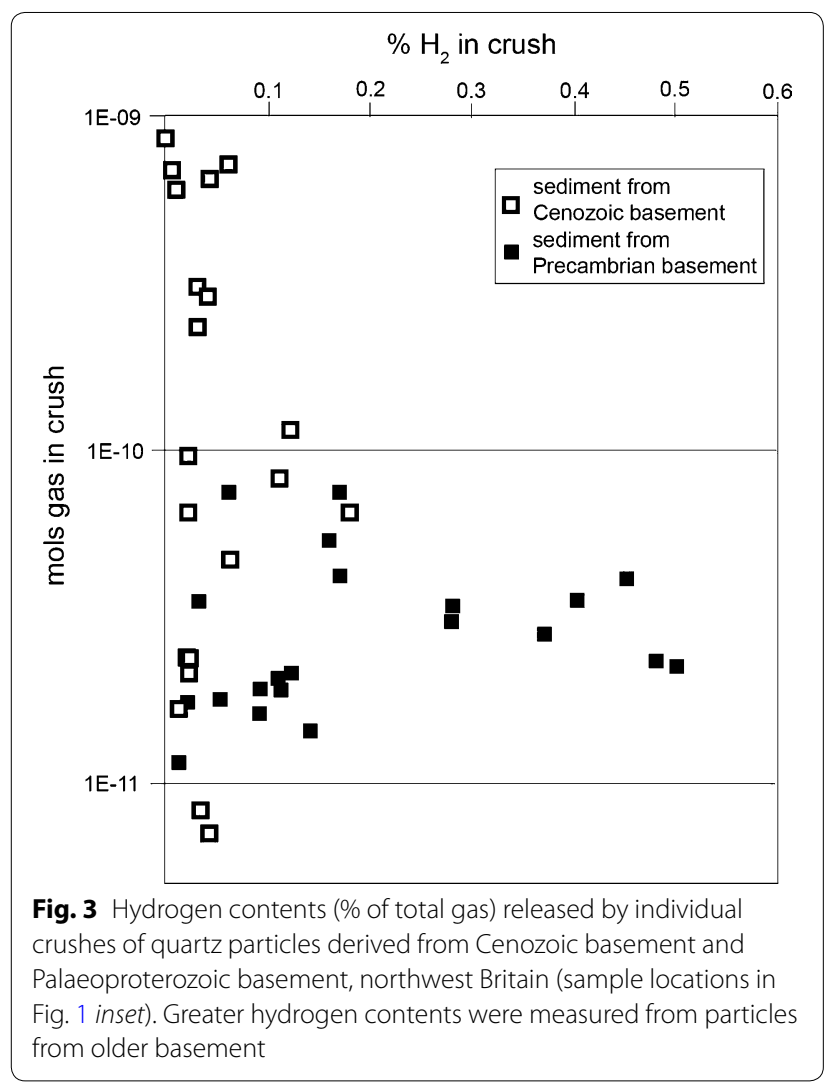

Mourne Mountains (Northern Ireland), Arran and Skye (Scotland) were compared with quartz particles in sediment derived from Proterozoic granites/gneisses in Islay, North Uist and Sutherlandshire (Scotland).

The cold crush method involves analysis by mass spectrometry conducted in high vacuum as described in [12-14]. Each session was preceded and followed by analysis of one microlitre capillary tubes for calibration. Atmosphere was also introduced to verify the calibration using 100-200 acquisitions for both the sample and atmosphere standard. A match head sized sample (about 250 microns) is crushed incrementally under a vacuum of $\sim 10^{-8}$ Torr, producing 6-10 successive bursts, which remained in the vacuum chamber for 8-10 analyser scans $(\sim 2 \mathrm{~s})$ before removal by the vacuum pump. This method does not require a carrier gas and volatiles are not separated from each other but released simultaneously into the chamber. The act of incremental crushing may open a single inclusion or multiple fluid inclusions. The data acquisition is performed by means of two Pfeiffer Prisma quadrupole mass spectrometers operating in fast-scan, peak-hopping mode. Routinely the system analyzes for the following gaseous species including $\mathrm{H}_{2}, \mathrm{He}, \mathrm{CH}_{4}$, $\mathrm{H}_{2} \mathrm{O}, \mathrm{N}_{2}, \mathrm{O}_{2}$, Ar, and $\mathrm{CO}_{2}$. The volatiles are reported in mol\%. The instrument is calibrated using Scott Gas Minimix gas mixtures (with $2 \%$ uncertainty), capillary tubes filled with gas mixtures (with $1 \%$ uncertainty), and three in-house fluid inclusion gas standards. The amount of each species is calculated by matrix multiplication [18] to provide a quantitative analysis. The 2-sigma detection limit for most inorganic species is about $0.2 \mathrm{ppm}$ for aqueous fluid inclusions. Instrumental blanks were also analyzed routinely to assess if gases were produced during the crushing process. The mass spectra remained at background during crushing of blanks indicating that gases released are not sourced from the crushers or hardware. Linearity of the mass spectrometer was confirmed up to nitrogen partial pressures of $10^{-6}$ Torr, which is orders of magnitude higher than routine operating pressures. The error across the linear range of the mass spectrometer is estimated from the standard deviation for capillary tube measurements of the $\mathrm{N}_{2} / \mathrm{Ar}$ ratio. This covers the noise and the area under the peak curve. The measurements indicate a maximum error of $1 \%$. Precision and accuracy vary between species. The amount of each species was calculated by matrix methods to provide a quantitative analysis, which is corrected for the instrumental background. Nine capillary tubes with encapsulated atmosphere were analyzed and yielded $\mathrm{N}_{2}$ / Ar ratios of 83.2 with a standard deviation of 1.4, within error of the atmospheric $\mathrm{N}_{2} / \mathrm{Ar}$ ratio of 83.6. This translates into $0.5 \%$ accuracy for artificial inclusions made under laboratory conditions. Precision using natural inclusions for the major gas species measured is generally $2-5 \%$, these being dependent on summed errors derived from instrument noise, linearity of the mass spectrometer, uncertainty of standards, blanks, interferences, and measurement of sensitivity factors. Before analysis, the crushing area and the bellows of the crusher 
were cleaned using potassium hydroxide. The apparatus is also routinely cleaned with isopropanol. Thereafter, the crushing chamber is baked at about $150-200{ }^{\circ} \mathrm{C}$ for $72 \mathrm{~h}$ before loading and analysing the samples at room temperature the next day. The crushing area is isolated from the main chamber so that the main chamber can be baked out every evening.

The hydrogen data is converted to the proportion of the non-aqueous component, to avoid misleading inferences from variations in the abundance of aqueous fluid inclusions, which dominate the entrained fluid.

\section{Data}

The data for the Precambrian basement samples (Table 1; Fig. 2) shows that consistently there is a hydrogen component to the entrained fluids. The mean value for the measurements is $0.142 \%$ non-aqueous gas. By contrast, the data for the younger basement samples are consistently in the range from 0 to $0.04 \%$, with a median value of $0.019 \%$, A single sample from the younger set, from Chile, yielded a high value of $0.13 \%$ : however, this sample was subsequently found to be from rocks being exploited for uranium, and so is excluded from the comparison. The total data set shows a marked difference between the older and younger basement samples, with an order of magnitude more hydrogen in the older samples. The modern sediment in northwest Britain yielded low hydrogen contents from the samples derived from Cenozoic sources, but higher hydrogen contents from some of the samples derived from Precambrian sources (Fig. 3).

\section{Discussion}

The database confirms previous theory $[1,2]$ that there is a global reservoir of hydrogen in crystalline basement and clarifies that it is resident particularly in old basement. The greater concentrations of hydrogen in the older rocks can be explained by the greater accumulated radioactivity, and hence radiolysis. A major proportion of the radioactivity is from potassium. In a coarse-grained rock like granite, beta-irradiation from potassium is more likely to penetrate beyond grain boundaries into intergranular fluid than shorter-range alpha irradiation from uranium, and potassium is also more pervasively distributed than the uranium in granite, so contributes more widely to radiolysis. Potassium is as abundant in the young basement as it is in the Precambrian basement (Fig. 2), showing that it is age rather than composition that is the control on hydrogen content. The hydrogen contents measured in modern sediments show that the gas signature of the basement rocks is conferred to the derived clasts. The more hydrogen-rich Precambrian basement is reflected in greater hydrogen contents in sediment derived from Precambrian basement than in sediment derived from Cenozoic basement. There are other mineral alteration mechanisms by which hydrogen can be generated in sediments on relatively short time scales (e.g. [19]), but the correlation of sediment provenance with hydrogen content shows that radiolysis is a major contributor.

The hydrogen entrained in basement and derived sediment is available for release by a variety of mechanisms, including solid state diffusion, strain deformation, fault movement and a range of surface erosion processes such as glacial grinding. Many of these mechanisms would involve decrepitation of the fluid inclusions, as is widely observed [20]. The availability of hydrogen in the subsurface in particular is important as a potential fuel for a deep biosphere [3, 21, 22]. Hydrogen may be the predominant source of energy for microbial activity in the subsurface, with a record back to the earliest life on Earth [23].

The signatures in old sediments will be a mixture of hydrogen generated in the provenance basement, and hydrogen generated by radiolysis since sediment deposition. As long as there is still a source of radioactivity, including potassium, radiolysis will continue, especially in fine-grained sediments where a greater proportion of the shorter range alpha irradiation may interact with pore waters [24]. This is conspicuously evident in the Oklo uranium deposits, Gabon, where fluid inclusions in sandstone contain discrete oxygen and hydrogen generated by radiolysis $[25,26]$. Where basement and derived sediment must differ in hydrogen generation is in the case of mineralogically mature sands consisting almost exclusively of quartz, where the potassium-bearing phases (especially feldspars) have been eliminated and the potassium becomes concentrated in clay/silt-sized minerals that are deposited under different hydrodynamic conditions. However the quartz may still retain hydrogen generated from adjacent mineral phases before basement and sediment erosion.

The availability of hydrogen in sedimentary basins may be as relevant, if not more so, to supporting a subsurface biosphere, than the availability of hydrogen in the parent basement. In contrast to basement rocks, in which deformation is episodic and spatially focussed, deformation in compacting basins proceeds relatively continuously and widely. Microfractures develop in compacting sands, even before they are fully lithified, and are rapidly rehealed as micron-scale planes containing entrapped fluid, extensively evident in cathodoluminescence images [27, 28]. However, there is evidence for low level availability of hydrogen in shallow sediment, where it is oxidized by microbes, but it is assumed that the hydrogen they process is derived from overlying atmosphere [29, 30]. Microbes also utilize hydrogen where it is available from 
Table 1 Contents of $\mathrm{H}_{2}, \mathrm{He}$, and mols of gas measured in samples of old and young basement, and sediments with old and young provenance

\begin{tabular}{|c|c|c|c|c|c|c|c|c|c|}
\hline Sample code/location & Rock type & $\mathrm{H}_{2}(\%)$ & $\mathrm{He}(\%)$ & $\mathrm{H}_{2} \mathrm{O}(\%)$ & $\mathrm{H}_{2}$ (\% non-water) & Mols gas & $\mathrm{K}_{2} \mathrm{O}(\%)$ & Age & References \\
\hline \multicolumn{10}{|l|}{ Old basement } \\
\hline JP210 Devon Is & Granite & 0.46 & 0.000 & 83.27 & 0.027 & $1.4 *-09$ & nd & $\sim 1.9 \mathrm{Ga}$ & {$[36]$} \\
\hline JP212 White Sea, Karelia & Granite & 0.04 & 0.000 & 93.23 & 0.006 & $6.1 *-10$ & 3.6 & $\sim 2.8 \mathrm{Ga}$ & {$[37,38]$} \\
\hline JP219 Chiobino, Karelia & Granite & 3.11 & 0.001 & 86.80 & 0.236 & $6.4^{*}-11$ & 3.6 & $\sim 2.8 \mathrm{Ga}$ & {$[37,38]$} \\
\hline JP200 Ceannabeinne & Gneiss & 1.67 & 0.000 & 97.14 & 0.584 & $3.3 *-10$ & 2.0 & $\sim 3.1 \mathrm{Ga}$ & {$[39]$} \\
\hline JP201 South Harris gneiss & Gneiss & 0.82 & 0.005 & 92.17 & 0.105 & $1.9 *-10$ & 0.6 & $1.88 \mathrm{Ga}$ & {$[39]$} \\
\hline JP147 Creighton, Sudbury & Granite & 2.03 & 0.005 & 96.17 & 0.530 & $5.4^{*}-11$ & 5.3 & $2.33 \mathrm{Ga}$ & {$[40,41]$} \\
\hline JP177 North Uist gneiss & Gneiss & 0.61 & 0.000 & 90.40 & 0.064 & $3.1^{*}-11$ & 2.7 & $\sim 3.1 \mathrm{Ga}$ & [39] \\
\hline JP92 Devon Is & Granite & 0.67 & 0.000 & 84.67 & 0.044 & $2.5^{*}-09$ & nd & $\sim 1.9 \mathrm{Ga}$ & {$[36]$} \\
\hline JP169 Barra & Gneiss & 0.17 & 0.000 & 92.49 & 0.023 & $5.7 *-10$ & 2.7 & $\sim 3.1 \mathrm{Ga}$ & [39] \\
\hline JP139 Moeda Fm & Conglomerate & 0.77 & 1.660 & 86.50 & 0.057 & $5.5^{*}-10$ & 0.6 & $\sim 2.5 \mathrm{Ga}$ & {$[42]$} \\
\hline 8852 Tarkwa & Conglomerate & 0.33 & & 80.20 & 0.017 & $3.1 *-10$ & 1.7 & $2.06 \mathrm{Ga}$ & {$[43,44]$} \\
\hline 9293 Shaw batholith (Aus) & Gneiss & 0.44 & 0.001 & 97.86 & 0.206 & $9.3^{*}-11$ & 2.1 & $3.45 \mathrm{Ga}$ & {$[45]$} \\
\hline $\begin{array}{l}9299 \text { Mt Edgar batholith } \\
\text { (Aus) }\end{array}$ & Gneiss & 0.10 & 0.001 & 99.47 & 0.189 & $8.3^{*}-11$ & 2.4 & $3.3 \mathrm{Ga}$ & {$[46]$} \\
\hline $\begin{array}{l}9298 \text { Swaziland Ngwane } \\
\text { gneiss }\end{array}$ & Gneiss & 0.25 & 0.012 & 97.87 & 0.117 & $1.2 *-10$ & 3.4 & $\sim 3.5 \mathrm{Ga}$ & [47] \\
\hline 9300 MSC105 Acasta TTG & Gneiss & 0.53 & 0.001 & 97.39 & 0.203 & $1.7^{*}-10$ & 0.4 & $\sim 4.0 \mathrm{Ga}$ & {$[48]$} \\
\hline 9301 MSC110 Acasta TTG & Gneiss & 0.15 & 0.000 & 97.44 & 0.059 & $3.0^{*}-10$ & 0.4 & $3.96 \mathrm{Ga}$ & [49] \\
\hline JP221 Gawler Craton (Aus) & Gneiss & 0.20 & 0.014 & 98.00 & 0.100 & $2.0^{*}-10$ & 3.2 & $\sim 2.5 \mathrm{Ga}$ & {$[50]$} \\
\hline JP224 Cullen (Aus) & Granite & 0.34 & 0.001 & 90.03 & 0.034 & $3.0 *-10$ & 5.0 & $1.76 \mathrm{Ga}$ & {$[51]$} \\
\hline JP233 Bass Lake Ontario & Granite & 0.10 & 0.000 & 97.78 & 0.045 & $1.8 *-10$ & nd & $\sim 2.7 \mathrm{Ga}$ & {$[52]$} \\
\hline KV3 Kaap Valley pluton SA & Tonalite & 0.78 & 0.003 & 94.46 & 0.141 & $8.4^{*}-11$ & 1.3 & $3.2 \mathrm{Ga}$ & [53] \\
\hline JP236 Rhinns Complex & Syenite & 0.84 & 0.000 & 92.41 & 0.111 & $1.1 *-10$ & 5.0 & $1.78 \mathrm{Ga}$ & {$[54,55]$} \\
\hline JP246 Nuuk, Greenland & Granite-gneiss & 2.72 & 0.004 & 74.92 & 0.108 & $1.1^{*}-10$ & 0.8 & $\sim 3.05 \mathrm{Ga}$ & {$[56]$} \\
\hline JP249 Gairloch Pier & Granite & 0.54 & 0.001 & 98.20 & 0.300 & $2.4^{*}-10$ & 2.2 & $1.9 \mathrm{Ga}$ & {$[57,58]$} \\
\hline JP262 Nanortalik, Greenland & Gneiss & 1.12 & 0.070 & 92.91 & 0.158 & $1.4^{*}-10$ & 4.0 & $\sim 1.8 \mathrm{Ga}$ & {$[59,60]$} \\
\hline KCL19 Liangchen, N China & Granulite & 1.29 & 0.001 & 86.36 & 0.095 & $7.1 *-11$ & 3.62 & $\sim 2.5 \mathrm{Ga}$ & {$[61]$} \\
\hline \multicolumn{10}{|l|}{ Young basement } \\
\hline JP205 Tibet & Granite & 0.00 & 0.000 & 94.38 & 0.000 & $7.1 *-10$ & 4.3 & $\sim 50 \mathrm{Ma}$ & {$[62]$} \\
\hline JP206 Tibet & Granite & 0.02 & 0.000 & 96.51 & 0.006 & $2.9 *-10$ & 4.3 & $\sim 50 \mathrm{Ma}$ & {$[62]$} \\
\hline JP207 Antarctic & Granodiorite & 0.14 & 0.000 & 96.59 & 0.041 & $1.5^{*}-10$ & 3.1 & $167 \mathrm{Ma}$ & {$[63,64]$} \\
\hline JP208 Antarctic & Granodiorite & 0.08 & 0.000 & 97.98 & 0.040 & $1.4^{*}-10$ & 4.7 & $167 \mathrm{Ma}$ & {$[63,64]$} \\
\hline JP209 Antarctic & Granodiorite & 0.15 & 0.001 & 93.50 & 0.023 & $3.7^{*}-10$ & 3.9 & $167 \mathrm{Ma}$ & {$[63,64]$} \\
\hline JP214 Nigeria & Granite & 0.00 & 0.000 & 81.85 & 0.000 & $2.0 *-09$ & 4.5 & $\sim 160 \mathrm{Ma}$ & {$[65]$} \\
\hline JP215 Nigeria & Granite & 0.02 & 0.000 & 62.06 & 0.001 & $6.8 *-09$ & 4.7 & $\sim 160 \mathrm{Ma}$ & {$[65]$} \\
\hline JP216 Fiji & Granite & 0.04 & 0.000 & 99.06 & 0.043 & $1.1 *-10$ & 1.2 & $\sim 15 \mathrm{Ma}$ & {$[66]$} \\
\hline JP218 Ireland & Granite & 0.10 & 0.000 & 97.34 & 0.038 & $3.1 *-10$ & 4.8 & $56 \mathrm{Ma}$ & {$[67,68]$} \\
\hline 9292 Chuqui, Chile & Granodiorite & 0.01 & 0.000 & 95.37 & 0.002 & $5.1 *-10$ & $\sim 6.0$ & $36 \mathrm{Ma}$ & {$[69,70]$} \\
\hline 9305 New Mexico Sugar Loaf & Grandiorite & 0.01 & 0.000 & 98.51 & 0.007 & $6.7^{*}-11$ & 3.9 & $35 \mathrm{Ma}$ & [71] \\
\hline JP223 Arran & Granite & 0.00 & 0.000 & 99.13 & 0.000 & $1.3^{*}-10$ & 4.9 & $60 \mathrm{Ma}$ & {$[67,72]$} \\
\hline JP232 Brazil & Syenite & 0.02 & 0.000 & 99.41 & 0.034 & $4.9 *-11$ & 8.0 & $79 \mathrm{Ma}$ & {$[73]$} \\
\hline JP234 Peru & Granodiorite & 0.10 & 0.000 & 96.68 & 0.030 & $8.2 *-11$ & 3.6 & $\sim 10 \mathrm{Ma}$ & [74] \\
\hline JP229 Skye & Granite & 0.03 & 0.000 & 98.37 & 0.018 & $3.0 *-10$ & 4.5 & $59 \mathrm{Ma}$ & {$[72,75]$} \\
\hline JP238 Montana & Syenite & 0.06 & 0.001 & 96.30 & 0.016 & $1.1 *-10$ & 6.5 & $\sim 52 \mathrm{Ma}$ & {$[76]$} \\
\hline NB New Mexico Questa & Granite & 0.07 & 0.000 & 95.93 & 0.017 & $1.7 *-10$ & 3.9 & $19 \mathrm{Ma}$ & {$[77]$} \\
\hline 9291 El Abra Chile & Granodiorite (U minztn) & 0.26 & 0.000 & 97.95 & 0.127 & $2.3 *-10$ & & $37 \mathrm{Ma}$ & {$[78,79]$} \\
\hline \multicolumn{10}{|l|}{ Sediments with old provenance } \\
\hline JP247 Gairloch Pier & & 0.54 & 0 & 96.92 & 0.175 & $2.6^{*}-10$ & & & \\
\hline
\end{tabular}


Table 1 continued

\begin{tabular}{|c|c|c|c|c|c|c|c|c|c|}
\hline Sample code/location & Rock type & $\mathrm{H}_{2}(\%)$ & $\mathrm{He}(\%)$ & $\mathrm{H}_{2} \mathrm{O}(\%)$ & $\mathrm{H}_{2}$ (\% non-water) & Mols gas & $\mathrm{K}_{2} \mathrm{O}(\%)$ & Age & References \\
\hline JP243A Portnahaven & & 0.13 & 0 & 97.28 & 0.048 & $1.6 *-10$ & & & \\
\hline JP248 Laxford & & 0.15 & 0 & 96.95 & 0.049 & $2.4^{*}-10$ & & & \\
\hline \multicolumn{10}{|c|}{ Sediments with young provenance } \\
\hline JP242A Red Cuillin, Skye & & 0.02 & 0 & 98.77 & 0.016 & $5.8 *-11$ & & & \\
\hline JP244 Bloody Bridge & & 0.07 & 0 & 98.68 & 0.053 & $3.9 *-10$ & & & \\
\hline JP245 Glen Sannox & & 0.027 & 0 & 91.02 & 0.003 & $4.4 *-09$ & & & \\
\hline
\end{tabular}

$\mathrm{K}_{2} \mathrm{O}$ content and ages from literature

deep sediment [31] and subsurface crystalline sources, especially through interaction of $\mathrm{Fe}(\mathrm{II})$ and water [4, 32-34]. These communities show that where hydrogen is available it is likely to be utilized and this will include hydrogen released from reservoirs in sedimentary rocks.

There is an implication for other rocky planets, which may similarly contain a subsurface reservoir of hydrogen derived from radiolysis, and thereby could support subsurface life. Notably, such life would not require surface water, and so would not be constrained by the 'Goldilocks Zone' commonly used to define the limits of habitability [35].

\section{Conclusions}

The measurement of entrained gases using the cold crush method show that hydrogen occurs in both basement and sediments. In detail:

1. Precambrian basement consistently contains entrained hydrogen, at levels an order of magnitude greater than in young $(<200 \mathrm{Ma})$ basement.

2. Modern sediment derived from old and young basement retains the signature of more or less hydrogen, respectively.

3. The high proportion of particles of early-mid Proterozoic age in modern sediments implies that relatively high levels of entrained hydrogen are held in much of that sediment.

These data show that reservoirs of hydrogen occur in both basement and sediment, available to support subsurface microbial activity.

\section{Authors' contributions}

JP instigated the project. NB undertook the measurements. Both authors prepared the final manuscript. Both authors read and approved the final manuscript.

\section{Author details}

${ }^{1}$ School of Geosciences, University of Aberdeen, Aberdeen AB24 3UE, UK.

${ }^{2}$ Department of Earth Sciences, Brock University, 500 Glenridge Avenue, St. Catharines, ON L2S 3A1, Canada.

\section{Acknowledgements}

The authors are grateful to the Science and Technology Facilities Council (STFC) for funding, through Grant NE/G00322X/1. Samples were kindly contributed by K. Condie, M.J. Hole, and D. Muirhead. We are grateful to reviewers for their criticism.

\section{Competing interests}

The authors declare that they have no competing interests.

\section{Availability of data and materials}

The datasets supporting the conclusions of this article are included within the article. Data are also available from Dr. Nigel Blamey (nblamey@brock.ca).

Received: 12 January 2017 Accepted: 14 March 2017

Published online: 20 March 2017

\section{References}

1. Sherwood Lollar B, Voglesonger K, Lin LH, Lacrampe-Couloume G, Telling J, Abrajano TA, Onstott TC, Pratt LM (2007) Hydrogeologic controls on episodic $\mathrm{H} 2$ release from Precambrian fractured rocks-energy for deep subsurface life on earth and mars. Astrobiology 7:971-986

2. Sherwood Lollar B, Onstott TC, Lacrampe-Couloume G, Ballentine CJ (2014) The contribution of the Precambrian continental lithosphere to Global H2 production. Nature 516:379-382

3. Freund F, Dickinson JT, Cash M (2002) Hydrogen in rocks: an energy source for deep microbial communities. Astrobiology 2:83-92

4. Lin LH, Slater GF, Sherwood Lollar B, Lacrampe-Couloume G, Onstott TC (2005) The yield and isotopic composition of radiolytic $\mathrm{H} 2$, a potential energy source for the deep subsurface biosphere. Geochim Cosmochim Acta 69:893-903

5. Lippmann-Pipke J, Sherwood Lollar B, Niedermann S, Stroncik NA, Naumann R, van Heerden E, Onstott TC (2011) Neon identifies two billion year old fluid component in Kaapvaal Craton. Chem Geol 283:287-296

6. Holland G, Sherwood Lollar B, Li L, Lacrampe-Couloume G, Slater GF, Ballentine CJ (2013) Deep fracture fluids isolated in the crust since the Precambrian era. Nature 497:357-360

7. Lowenstern JB, Evans WC, Bergfeld D, Hunt AG (2014) Prodigious degassing of a billion years of accumulated radiogenic helium at yellowstone. Nature 506:355-358

8. Voice PJ, Kowalewski M, Eriksson KA (2011) Quantifying the timing and rate of crustal evolution: global compilation of radiometrically dated detrital zircon grains. J Geol 119:109-126

9. Condie KC, Bickford ME, Aster RC, Belousova E, Scholl DW (2011) Episodic zircon ages, $\mathrm{Hf}$ isotopic composition, and the preservation rate of continental crust. Geol Soc Am Bull 123:951-957

10. Condie KC (2005) Earth as an evolving planetary system. Academic Press, Amsterdam

11. Hawkesworth CJ, Dhuime B, Pietranik AB, Cawood PA, Kemp AIS, Storey CD (2010) The generation and evolution of the continental crust. J Geol Soc 167:229-248 
12. Norman DI, Blamey NJF (2001) Quantitative analysis of fluid inclusion volatiles by a two quadrupole mass spectrometer system. ECROFI $\mathrm{XVl}: 341-344$

13. Blamey NJF (2012) Composition and evolution of crustal, geothermal and hydrothermal fluids interpreted using quantitative fluid inclusion gas analysis. J Geochem Explor 116-117:17-27

14. Blamey NJF, Parnell J, McMahon S, Mark D, Tomkinson T, Lee M, Shivak J, Izawa M, Banerjee N, Flemming R (2015) Evidence for methane in martian meteorites. Nature Commun. doi:10.1038/ncomms8399

15. Thomas R, Davidson $P$ (2012) Water in granite and pegmatite-forming melts. Ore Geol Rev 46:32-46

16. Thomas R, Förster HJ, Rickers K, Webster JD (2005) Formation of extremely F-rich hydrous melt fractions and hydrothermal fluids during differentiation of highly evolved tin-granite magmas: a melt/fluid-inclusion study. Contrib Miner Petrol 148:582-601

17. Eugster HP (1985) Granites and hydrothermal ore deposits: a geochemical framework. Miner Mag 49:7-23

18. Isenhour TL, Jurs PC (1972) Introduction to computer programming for chemists. Allyn \& Baco, Boston, p 325

19. Neubeck A, Duc NT, Hellevang H, Oze C, Bastviken D, Bacsik Z, Holm NG (2014) Olivine alteration and $\mathrm{H} 2$ production in carbonate-rich, low temperature aqueous environments. Planet Space Sci 96:51-61

20. Roedder $\mathrm{E}$ (1972) Composition of fluid inclusions. US Geol Surv Prof Paper 440JJ:1-164

21. Lin LH, Wang PL, Rumble D, Lippmann-Pipke J, Boice EA, Pratt LM, Sherwood Lollar B, Brodie EL, Hazen TC, Anderson GL, DeSantis TZ, Moser DP, Kershaw D, Onstott TC (2006) Long-term sustainability of a high-energy, low-diversity crustal biome. Science 314:479-482

22. Sleep NH, Bird DK (2007) Niches of the pre-photosynthetic biosphere and geologic preservation of earth's earliest ecology. Geobiology 5:101-117

23. Ueno Y, Yamada K, Yoshida N, Maruyama S, Isozaki Y (2006) Evidence from fluid inclusions for microbial methanogenesis in the early Archaean era. Nature 440:516-519

24. Blair CC, D'Hondt S, Spivack AJ, Kingsley RH (2007) Radiolytic hydrogen and microbial respiration in subsurface sediments. Astrobiology 7:951-970

25. Dubessy J, Pagel M, Beny J-M, Christensen H, Hickel B, Kosztolanyi C, Poty $\mathrm{B}$ (1988) Radiolysis evidenced by H2-O2 and H2-bearing fluid inclusions in three uranium deposits. Geochim Cosmochim Acta 52:1155-1167

26. Savary $\vee$, Pagel M (1997) The effects of water radiolysis on local redox conditions in the Oklo, Gabon, natural fission reactors 10 and 16. Geochim Cosmochim Acta 61:4479-4494

27. Milliken KL, Laubach SE (2000) Brittle deformation in sandstone diagenesis as revealed by scanned cathodoluminescence imaging with application to characterization of fractured reservoirs. In: Pagel M, Barbin V, Blanc P, Ohnenstetter D (eds) Cathodoluminescence in geosciences. Springer, New York, pp 225-243

28. Anders MH, Laubach SE, Scholz CH (2014) Microfractures: a review. J Struct Geol 69:377-394

29. Klüber HD, Lechner S, Conrad R (1995) Characterization of populations of aerobic hydrogen-oxidizing soil bacteria. FEMS Microbiol Ecol 16:167-175

30. Pumphrey GM, Ranchou-Peyruse A, Spain JC (2011) Cultivation-independent detection of autotrophic hydrogen-oxidizing bacteria by DNA stable-isotope probing. Appl Environ Microbiol 77:4931-4938

31. Adhikari RR, Glombitza C, Nickel JC, Anderson CH, Dunlea AG, Spivack AJ, Murray RW, D'Hondt S, Kallmeyer J (2016) Hydrogen utilization potential in subsurface sediments. Front Microbiol. doi:10.3389/fmicb.2016.00008

32. Stevens KO, McKinley JP (2000) Abiotic controls on $\mathrm{H} 2$ production from basalt-water reactions and implications for aquifer biogeochemistry. Environ Sci Technol 34:826-831

33. Spear JR, Walker JJ, McCollum TM, Pace NR (2005) Hydrogen and bioenergetics in the yellowstone geothermal ecosystem. Proc Natl Acad Sci USA 102:2555-2560

34. Mayhew LE, Ellison ET, McCollum TM, Trainor TP, Templeton AS (2013) Hydrogen generation from low-temperature water-rock interactions. Nat Geosci 6:478-484

35. Kasting JF, Whitmire DP, Reynolds RT (1993) Habitable zones around main sequence stars. Icarus 101:108-128

36. Frisch T, Trettin HP (1991) Precambrian successions in the northernmost part of the Canadian Shield. In: Trettin HP (ed) Geology of the Innuitian Orogen and Arctic Platform of Canada and Greenland. Geological Survey of Canada, Ottowa, pp 179-184
37. Bogdanova SV, Bibikova EV (1993) The 'Saamian' of the Belomorian mobile belt: new geochronological constraints. Precambr Res 64:131-152

38. Krats KO, Lobach-Zhuchenko SB, Chekulayev VP (1971) Early Precambrian granitogenesis in Baltic Shield (geochemical aspect). Int Geol Rev 13:234-241

39. Fettes DJ, Mendum JR, Smith DI, Watson JV (1992) Geology of the outer hebrides. Memoir of the British Geological Survey, London

40. Frarey MJ, Loveridge WD, Sullivan RW (1982) A U-Pb zircon age for the Creighton Granite, Ontario. Geol Surv Canada Pap 81-1C:129-132

41. Murphy El (1999) Geology, metamorphism and geochemistry of Southern and Grenville Province rocks in the vicinity of the Grenville Front, Timmins Creek area, near Sudbury, Ontario. Unpublished MSc Thesis, Laurentian University

42. Minter WEL, Renger FE, Siegers A (1990) Early Proterozoic gold placers of the Moeda Formation within the Gandarela Syncline, Minas Gerais, Brazil. Econ Geol 85:943-951

43. Pigois JP, Groves DI, Fletcher IR, McNaughton NJ, Snee LW (2003) Age constraints on Tarkwaian palaeoplacer and lode-gold formation in the Tarkwa-Damang district, SW Ghana. Miner Depos 38:695-714

44. Amoako FY, Poellmann H, Gossel W (2011) Immobilisation of hazardous substances from mine tailings using mineral reservoir technology: case of mineral processing tailings from Ghana. Mine water-managing the challenges. IMWA, Aachen, pp 259-264

45. Bickle MJ, Bettenay LF, Chapman HJ, Groves DI, McNaughton NJ, Campbell IH, de Laeter JR (1993) Origin of the 3500-3300 Ma calc-alkaline rocks in the Pilbara Archaean: isotopic and geochemical constraints from the Shaw Batholith. Precambr Res 60:117-149

46. Collins WJ (1993) Melting of Archaean sialic crust under high aH2O conditions: genesis of the $330 \mathrm{Ma} \mathrm{Na-rich} \mathrm{granitoids} \mathrm{in} \mathrm{the} \mathrm{Mount}$ Edgar Batholith, Pilbara Block, Western Australia. Precambr Res 60:151-174

47. Kröner A, Compston W, Williams IS (1989) Growth of early Archaean crust in the Ancient Gneiss Complex of Swaziland as revealed by single zircon dating. Tectonophysics 161:271-298

48. Bowring SA, Williams IS (1999) Priscoan (4.00-4.03 Ga) orthogneisses from northwestern Canada. Contrib Miner Petrol 134:3-16

49. Bowring SA, Williams IS, Compston W (1989) 3.96 Ga gneisses from the Slave province, Northwest Territories, Canada. Geology 17:971-975

50. McFarlane CRM, Mavrogenes JA, Tomkins AG (2007) Recognizing hydrothermal alteration through a granulite facies metamorphic overprint at the Challenger Au deposit, South Australia. Chem Geol 243:64-89

51. Ewers GR, Scott PA (1977) Geochemistry of the Cullen Granite, Northern Territory. BMR J Aust Geol Geophys 2:165-176

52. Thurston PC, Williams HR, Sutcliffe RH, Stott GM (1991) Geology of Ontario. Ministry of Northern Development and Mines, Ottawa

53. Layer PW, Kröner A, York D (1992) Pre-3000 Ma thermal history of the Archean Kaap Valley pluton, South Africa. Geology 20:717-720

54. Marcantonio F, Dickin AP, McNutt RH, Heaman LM (1988) A 1800-millionyear-old Proterozoic gneiss terrane in Islay with implications for the crustal structure and evolution of Britain. Nature 335:62-64

55. Muir RJ, Fitches WR, Maltman AJ (1994) The Rhinns Complex: proterozoic basement on Islay and Colonsay, Inner Hebrides, Scotland, and on Inishtrahull, NW Ireland. Trans R Soc Edinburgh: Earth Sci 85:77-90

56. Dymek RF, Smith MS (1990) Geochemistry and origin of Archaean quartzcordierite gneisses from the Godthåbsfiord region, West Greenland. Contrib Miner Petrol 105:715-730

57. Park RG, Tarney J, Connelly JN (2001) The Loch Maree Group: Palaeoproterozoic subduction-accretion complex in the Lewisian of NW Scotland. Precambr Res 105:205-226

58. Park RG (2002) The Lewisian geology of Gairloch, NW Scotland. Geological Society, London, p 26

59. Kalsbeek F, Taylor PN (1985) Isotopic and chemical variation in granites across a Proterozoic continental margin-the Ketilidian mobile belt of South Greenland. Earth Planet Sci Lett 73:65-80

60. Garde AA, Chadwick B, Grocott J, Hamilton MA, McCaffrey KJW, Swager CP (2002) Mid-crustal partitioning and attachment during oblique convergence in an arc system, Palaeoproterozoic Ketilidian orogeny, southern Greenland. J Geol Soc London 159:247-261

61. Condie KC, Boryta MD, Liu J, Qian X (1992) The origin of khondalites: geochemical evidence from the Archean to Early Proterozoic granulite belt in the North China craton. Precambr Res 59:207-223 
62. Debon F, Le Fort P, Sheppard SMF, Sonet J (1986) The four plutonic belts of the Transhimalaya-Himalaya: a chemical, mineralogical, isotopic and chronological synthesis along a Tibet-Nepal section. J Petrol 27:219-250

63. Pankhurst RJ (1982) Rb-Sr geochronology of Graham Land, Antarctica. J Geol Soc Lond 139:701-711

64. Hole MJ (1986) Time controlled geochemistry of igneous rocks of the Antarctic Peninsula. Unpublished Ph.D. Thesis, University of London

65. Turner DC, Webb PK (1974) The Daura igneous complex, N Nigeria; a link between the Younger Granite districts of Nigeria and S Niger. J Geol Soc Lond 130:71-77

66. Colley H (1984) An ophiolite suite in Fiji?. Geological Society, London, pp $333-340$

67. Meighan IG, Gibson D, Hood DN (1984) Some aspects of tertiary acid magmatism in NE Ireland. Miner Mag 48:351-363

68. Gibson D, Lux DR, Meighan IG (1995) New 40Ar/39Ar ages for the Mourne Mountains granites, North-East Ireland. Irish J Earth Sci 14:25-35

69. Cornejo P, Tosdal RM, Mpodozis C, Tomlinson AJ, Rivera O, Fanning CM (1997) Chile porphyry copper deposit revisited: geologic and geochronologic framework. Int Geol Rev 39:22-54

70. Ossandón G, Fréraut R, Gustafson LB, Lindsay DD, Zentilli M (2001) Geology of the Chuquicamata Mine: a progress report. Econ Geol 96:249-270

71. Zimmerer MJ, McIntosh WC (2013) Geochronologic evidence of uppercrustal in situ differentiation: silicic magmatism at the Organ caldera complex, New Mexico. Geosphere 9:1-15
72. Stoker MS, Hitchen K, Graham CC (1993) United Kingdom Offshore Regional Report: the geology of the Hebrides and West Shetland shelves, and adjacent deep-water areas. HMSO, London

73. Ulbrich HH, Vlach SRF, Demaiffe D, Ulbrich MNC (2005) Structure and origin of the Poços de Caldas alkaline massif, SE Brazil. In: Comin-Chiaramonti P, Gomes CB (eds) Mesozoic to Cenozoic Alkaline Magmatism in the Brazilian Platform. Fapeso, Sao Paulo, pp 367-418

74. Petford N, Atherton M (1996) Na-rich partial melts from newly underplated basaltic crust: the Cordillera Blanca Batholith, Peru. J Petrol 37:1491-1521

75. Thompson RN (1969) Tertiary granites and associated rocks of the Marsco area, Isle of Skye. Q J Geol Soc Lond 124:349-385

76. O'Brien HE, Irving AJ, McCallum IS (1991) Eocene potassic magmatism in the Highwood Mountains, Montana: petrology, geochemistry, and tectonic implications. J Geophys Res 96:B13237-B13260

77. Johnson CM, Czamanske GK, Lipman PW (1989) Geochemistry of intrusive rocks associated with the Latir volcanic field, New Mexico, and contrasts between evolution of plutonic and volcanic rocks. Contrib Miner Petrol 103:90-109

78. López-Escobar L, Frey FA, Oyarzún J (1979) Geochemical characteristics of central Chile $\left(33^{\circ}-34^{\circ} \mathrm{S}\right)$ granitoids. Contrib Miner Petrol 70:439-450

79. Campbell IH, Ballard JR, Palin JM, Allen C, Faunes A (2006) U-Pb zircon geochronology of granitic rocks from the Chuquicamata-El Abra porphyry copper belt of northern Chile: excimer laser ablation ICP-MS analysis. Econ Geol 101:1327-1344

\section{Submit your manuscript to a SpringerOpen ${ }^{\odot}$ journal and benefit from:}

- Convenient online submission

Rigorous peer review

- Immediate publication on acceptance

- Open access: articles freely available online

- High visibility within the field

- Retaining the copyright to your article

Submit your next manuscript at springeropen.com 